\title{
EFFECT OF SPRINKLER IRRIGATION ON YIELD INCREASING OF CARROT ROOTS OBTAINED IN CULTIVATION ON LIGHT SOIL IN DIFFERENT REGIONS OF POLAND
}

\author{
Barbara Jagosz ${ }^{1}$, Stanislaw Rolbiecki ${ }^{2}$, Roman Rolbiecki ${ }^{2}$, Anna Figas ${ }^{3}$, Wieslaw Ptach ${ }^{4}$ \\ ${ }^{1}$ University of Agriculture in Krakow, Poland; ${ }^{2}$ University of Science and Technology, Poland; ${ }^{3}$ UTP \\ University of Science and Technology in Bydgoszcz, Poland; \\ ${ }^{4}$ Warsaw University of Life Sciences, Poland \\ b.jagosz@ogr.ur.krakow.pl, rolbs@utp.edu.pl,wieslaw_ptach@sggw.pl
}

\begin{abstract}
The purpose of this study was to estimate the expected effects of sprinkler irrigation, applied depending on the rainfall amounts, on the yield increasing of marketable carrot roots (Daucus carota L.). The experiment was performed on light soil in different regions of Poland at the critical period considered from May $1^{\text {st }}$ to July $31^{\text {st }}$. A straight line relationship between the yield increase and the use of sprinkler irrigation depending on the amount of precipitation was adapted. The carrot roots yield was determined for five agroclimatic regions of Poland. The amount of rainfall in the average dry years $\left(P_{50 \%}\right)$, medium dry years $\left(P_{25 \%}\right)$ and very dry years $\left(P_{10 \%}\right)$ was defined by the Ostromęcki method. The largest precipitation deficit in the cultivation of carrot during the critical period in the average dry years and medium dry years was found in the C-N-W region of Poland. In the very dry years the largest rainfall deficit was in the C-E region of Poland. The smallest precipitation deficiency was noted in the S-E region of Poland. The highest increase of the roots yield, observed as the influence of sprinkler irrigation applied during the average dry years and medium dry years, is expected in the $\mathrm{C}-\mathrm{N}-\mathrm{W}$ region of Poland. In the very dry years the largest raise of the roots yield can be expected in the C-E region of Poland. The predictable production effects of sprinkler irrigation, estimated in the present study, show a great possibility of increasing of carrot roots marketable yield in field cultivation under optimum water conditions.
\end{abstract}

Keywords: Daucus carota L., precipitation deficiencies, vegetable, water requirements.

\section{Introduction}

The water requirements of carrot plants during the growing season in Poland ranged from 300 to $400 \mathrm{~mm}$ [1-3]. According to [4;5], the water needs of new, high-yielded carrot cultivars are large and vary between 350 and $400 \mathrm{~mm}$. The rainfall requirements of carrot plants, i.e. optimum precipitation for this vegetable species, in the cultivation on the light soil in the central region of Poland amount to $245 \mathrm{~mm}$ for the early-yielded cultivars and $385 \mathrm{~mm}$ for the late-yielded cultivars [3]. During dry years, the rainfall requirements of the late-yielded cultivars of carrot grown on the light soil are: $390 \mathrm{~mm}$ in lowlands and upland highlands, $340 \mathrm{~mm}$ in Pomerania, as well as Warmia and Masuria, and $360 \mathrm{~mm}$ in the Land of Great Valleys; and the water deficits are maintained there at 90,100 and $110 \mathrm{~mm}$, respectively [2].

The objective of this research was to calculate the expected effects of sprinkler irrigation treatment, applied depending on the precipitation amounts, on the marketable yield increasing of carrot roots during the cultivation on the light soil in five different regions of Poland at the critical period considered from May $1^{\text {st }}$ to July $31^{\text {st }}$.

\section{Materials and methods}

In the current study a straight line relationship formula (1) between the marketable yield increase of carrot roots (Daucus carota L.) and the sprinkler irrigation, applied depending on the amount of precipitation during the critical period (from May $1^{\text {st }}$ to July $31^{\text {st }}$ ), was adapted according to Grabarczyk proposal [6].

$$
Q=\left(P_{o p t}-P_{r z}\right) q,
$$

where $Q$-yield increase under the influence of irrigation, $\mathrm{kg} \cdot \mathrm{ha}^{-1}$;

$P_{\text {opt }}$ - optimal precipitation amount in the period of increasing water needs, $\mathrm{mm}$;

$P_{r z}$ - real precipitation amount in the period of increasing water needs, $\mathrm{mm}$;

$q$ - yield increase under the influence of sprinkler irrigation, $\mathrm{kg} \cdot \mathrm{ha}^{-1}$ per $1 \mathrm{~mm}$ of the atmospheric precipitation deficit. 
The evaluation of the yield increase of marketable carrot roots, observed as the influence of sprinkler irrigation applied depending on the precipitation amount during the period from May $1^{\text {st }}$ to July $31^{\text {st }}$, was performed according to Rolbiecki [7] method (2).

$$
Q=\left(252-P_{r z}\right) 219 \text {, }
$$

where $Q-$ yield increase under the influence of irrigation, $\mathrm{kg} \cdot \mathrm{ha}^{-1}$;

$P_{r z}-$ real precipitation amount in the period of increasing water needs, $\mathrm{mm}$.

The marketable yield of carrot roots was determined for five agro-climatic regions of Poland with the representative meteorological stations located in Olsztyn, Bydgoszcz, Warsaw, Wrocław and Kraków, according to the description presented in Figure 1 [8].

The amount of precipitation during the average dry years $\left(P_{50 \%}\right)$, medium dry years $\left(P_{25 \%}\right)$ and very dry years $\left(P_{10 \%}\right)$ was defined by the Ostromęcki method [9;10], using the $B p \%$ coefficients, which determined the variability of rainfall in the particular meteorological stations. The calculations were based on the precipitation amounts data in the years 1981-2010. The rainfall deficit was determined, using the difference between optimum precipitation $\left(P_{o p t}\right)$ and real precipitation $\left(P_{r z}\right)$ at the particular meteorological stations.

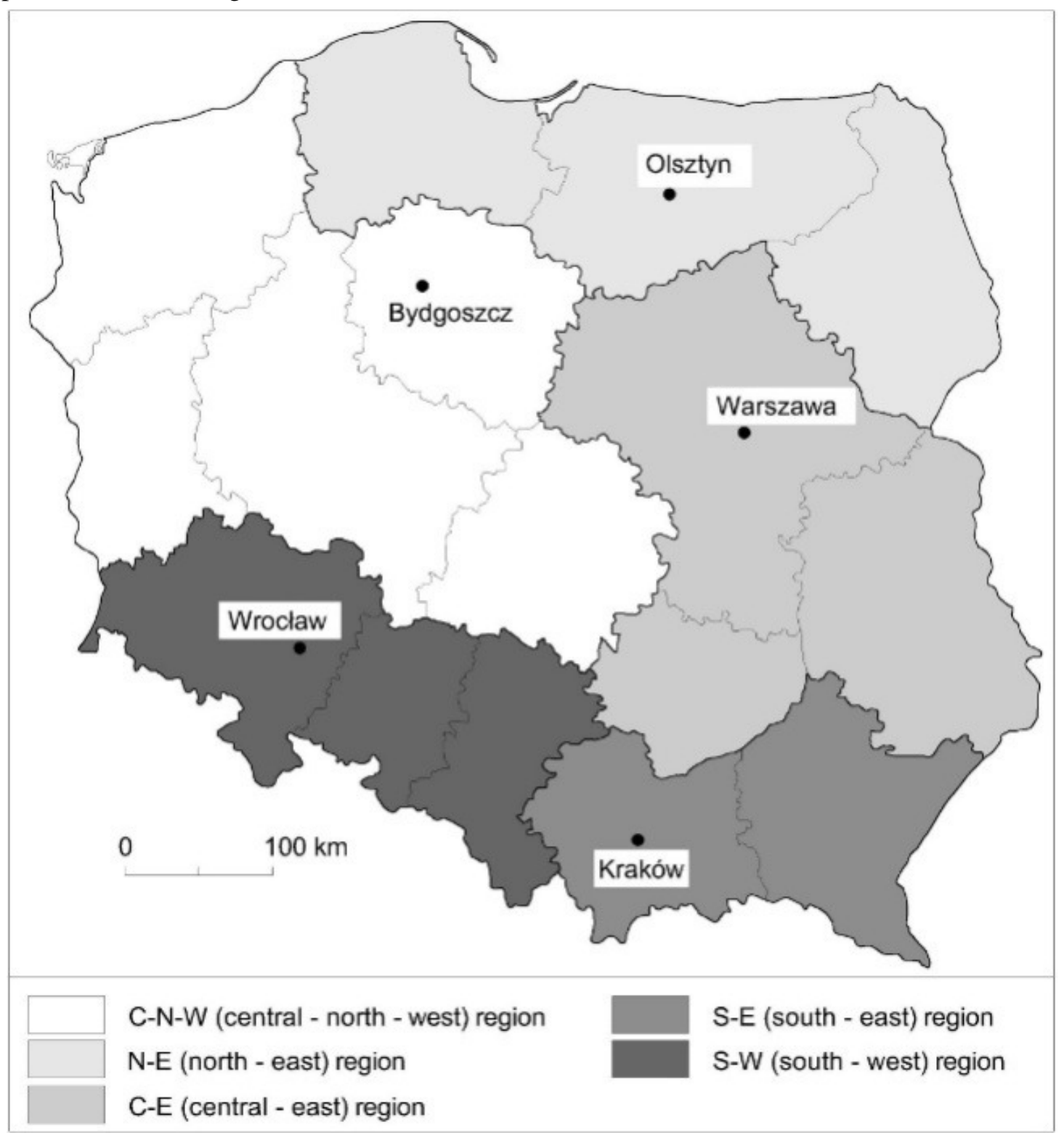

Fig. 1. Agro-climatic regions of Poland with representative meteorological stations according to Labędzki [8] 


\section{Results}

During the average dry years the largest precipitation deficit $(74 \mathrm{~mm})$ occurred in the C-N-W region of Poland, smaller rainfall deficiencies were observed in the N-E, C-E and S-W regions of the country, where they amounted to 43, 45 and $46 \mathrm{~mm}$, respectively (Tab. 1). While in the S-E region of Poland small precipitation excess $(4 \mathrm{~mm})$ was found. In the medium dry years the highest rainfall deficiencies $(143 \mathrm{~mm})$ also were noted in the $\mathrm{C}-\mathrm{N}-\mathrm{W}$ region of Poland and the lowest precipitation deficit $(70 \mathrm{~mm})$ in the $\mathrm{S}-\mathrm{E}$ region of the country was detected. During the very dry years the largest rainfall deficiencies $(172 \mathrm{~mm})$ occurred in the C-E region of Poland and the smallest precipitation deficit $(100 \mathrm{~mm})$ in the $\mathrm{S}$-E region of the country was observed.

\section{Precipitation deficiencies $(\mathrm{mm})$ in carrot cultivation in the period July-August in different regions of Poland}

Table 1

\begin{tabular}{|c|c|c|c|c|c|c|}
\hline \multirow{2}{*}{$\begin{array}{l}\text { Year in terms of } \\
\text { the amount of } \\
\text { precipitation }\end{array}$} & \multirow{2}{*}{$\begin{array}{c}\text { Probability }(P) \text { of } \\
\text { occurrence } \% \text { of } \\
\text { years }\end{array}$} & \multicolumn{5}{|c|}{ Region of Poland } \\
\hline & & N-E & C-N-W & C-E & S-W & S-E \\
\hline Average dry & 50 & 43 & 74 & 45 & 46 & -4 \\
\hline Medium dry & 25 & 118 & 143 & 130 & 106 & 70 \\
\hline Very dry & 10 & 150 & 156 & 172 & 156 & 100 \\
\hline
\end{tabular}

Based on the presented calculations, it was found that the highest increase of the marketable carrot roots yield $\left(16.21 \mathrm{t} \cdot \mathrm{ha}^{-1}\right)$, noted as the effect of sprinkler irrigation treatment applied during the average dry years, can be expected in the C-N-W region of Poland (Tab. 2). Whereas in the S-E region of the country the sprinkler irrigation of carrot plants may not bring any production effects due to sufficient amount of precipitation. In the medium dry years the increase of the carrot marketable yield, observed as the effect of sprinkler irrigation treatment, also in the $\mathrm{C}-\mathrm{N}-\mathrm{W}$ region of Poland was the largest $\left(31.33 \mathrm{t} \cdot \mathrm{ha}^{-1}\right)$, while the smallest increase of the root yield $\left(15.41 \mathrm{t} \cdot \mathrm{ha}^{-1}\right)$ can be expected in the S-E region of the country. During the very dry years the highest raise of the carrot roots yield $\left(37.63 \mathrm{t} \cdot \mathrm{ha}^{-1}\right)$ should be anticipated in the C-E region of Poland, whilst the lowest $\left(22.01 \mathrm{t} \cdot \mathrm{ha}^{-1}\right)$ in the S-E region of the country.

Table 2

Expected increase of carrot roots yield $\left(\mathrm{t} \cdot \mathrm{ha}^{-1}\right)$ observed as the effect of sprinkler irrigation in the different regions of Poland

\begin{tabular}{|c|c|c|c|c|c|c|}
\hline \multirow{2}{*}{$\begin{array}{l}\text { Year in terms of } \\
\text { the amount of } \\
\text { precipitation }\end{array}$} & \multirow{2}{*}{$\begin{array}{c}\text { Probability }(P) \text { of } \\
\text { occurrence } \% \text { of } \\
\text { years }\end{array}$} & \multicolumn{5}{|c|}{ Region of Poland } \\
\hline & & N-E & C-N-W & C-E & S-W & S-E \\
\hline Average dry & 50 & 9.38 & 16.21 & 9.95 & 10.14 & - \\
\hline Medium dry & 25 & 25.81 & 31.33 & 28.36 & 23.17 & 15.41 \\
\hline Very dry & 10 & 32.74 & 34.26 & 37.63 & 34.16 & 22.01 \\
\hline
\end{tabular}

\section{Discussion}

In the present study a significant relationship between the increase of the carrot roots yield and the sprinkler irrigation applied, depending on the precipitation amount during the period of high water requirements of the plants, was investigated [7]. The mathematical formula that defines the above dependence presents the increase of the carrot roots marketable yield as the influence of sprinkler irrigation applied during the period of rainfall deficiency (lower than $252 \mathrm{~mm}$ ) i.e. from May $1^{\text {st }}$ to July $31^{\text {st }}$. The estimated assessment of precipitation deficit in the critical period (May-July) during the cultivation of carrot plants, which consists in comparing the calculated rainfall needs with real atmospheric precipitation in a given region of Poland $\left(P_{50 \%}, P_{25 \%}\right.$ and $\left.P_{10 \%}\right)$, has shown the largest precipitation deficiency in the central Poland (C-N-W and C-E regions). Comparable results have already been previously published [6;7;11-13].

The prognostic formula, developed on the basis of the field experiments allowed, depending on the amount of rainfall, to estimate the effects of sprinkler irrigation of the carrot plants grown on the light soil in the different regions of Poland. Similar researches, based on the species such as cucumber 
and celeriac, have already been previously reported [7;11]. The expected production effects of sprinkler irrigation applying, observed in the present study, show a large possibility of increasing of the carrot roots yield in field cultivation under optimum water conditions.

It is believed that the observed climate changes (including the raise of temperature) in the near future will cause a significant increase of the water needs of plants, including vegetable species grown under field conditions [14-18]. Therefore, it is necessary to undertake the adaptation actions, such as the irrigation techniques, which will rise in importance with the intensification of unfavourable climate changes. Apart from the forecasted disadvantageous climate changes, the need for higher, stable and good quality vegetable yield [19;20], as well as the expectation of increasing modernity and competitiveness of the horticultural and agricultural farms [13] also influence the development of irrigation treatments.

\section{Conclusions}

1. The highest precipitation deficiencies in the cultivation of carrot plants, observed during the critical period (from May $1^{\text {st }}$ to July $31^{\text {st }}$ ) in the average dry years and medium dry years, was found in the C-N-W region of Poland. During the very dry years the highest rainfall deficit occurs in the C-E region of the country. The lowest precipitation deficiency was noted in the S-E region of Poland.

2. The highest increase of the marketable carrot roots yield, observed as the influence of sprinkler irrigation applied during the average dry years and medium dry years, is expected in the C-N-W region of the country. In the very dry years the highest raise of the marketable carrot roots yield can be expected in the C-E region of Poland.

\section{References}

[1] Kaniszewski S. Nawadnianie warzyw. Warszawa: PWRiL, 1987. 108 p. (In Polish).

[2] Dzieżyc J. Rolnictwo w warunkach nawadniania. Warszawa: PWN, 1988. 415 p. (In Polish).

[3] Buczak E. Potrzeby wodne roślin warzywnych. In: J. Dzieżyc (Editor) Potrzeby wodne roślin, Warszawa: PWN, 1989. 159-188 pp. (In Polish).

[4] Kaniszewski S. Nawadnianie warzyw polowych. Kraków: Plantpress, 2005. 85 p. (In Polish).

[5] Kaniszewski S. Nawadnianie warzyw. In: S. Karczmarczyk \& L. Nowak (Editors). Nawadnianie roślin, Poznań: PWRiL, 2006. 295-332 pp. (In Polish).

[6] Grabarczyk S. Efekty, potrzeby i możliwości nawodnień deszczownianych w różnych regionach kraju. Zeszyty Problemowe Postępów Nauk Rolniczych, vol. 314, 1986, pp. 49-64. (In Polish).

[7] Rolbiecki S., Żarski J., Grabarczyk S. Yield-irrigation relationships for field vegetable crops grown in Central Poland. Acta Horticulturae, vol. 537, no. 2, 2000, pp. 867-870.

[8] Łabędzki L., Bąk B., Liszewska M. Wpływ przewidywanej zmiany klimatu na zapotrzebowanie ziemniaka późnego na wodę. Infrastructure and Ecology of Rural Areas, vol. 2, no. I, 2013, pp. 155-165. (In Polish).

[9] Żakowicz S., Hewelke P. Wybrane materiały meteorologiczne. Warszawa: SGGW, 1995. 356 p. (In Polish).

[10]Żakowicz S., Hewelke P., Gnatowski T. Podstawy infrastruktury technicznej w przestrzeni produkcyjnej. Warszawa: SGGW, 2009. 192 p. (In Polish).

[11]Żarski J. Zwyżki plonów ogórków gruntowych i selerów pod wpływem deszczowania a opady atmosferyczne w okresie krytycznym. Zeszyty Problemowe Postępów Nauk Rolniczych, vol. 343, 1989, pp. 67-73. (In Polish).

[12] Stachowski P., Markiewicz J. The need of irrigation in central Poland on the example of Kutno county. Annual Set of Environment Protection, vol. 13, 2011, pp. 1453-1472.

[13]Żarski J., Dudek S., Kuśmierek-Tomaszewska R., Rolbiecki R., Rolbiecki S. Forecasting effects of plants irrigation based on selected meteorological and agricultural drought indices. Annual Set The Environment Protection, vol. 1, 2013, pp. 2185-2203.

[14] Łabędzki L. Foreseen climate changes and irrigation development in Poland. Infrastructure and Ecology of Rural Areas, vol. 3, 2009, pp. 7-18.

[15] Kuchar L., Iwański S. Rainfall simulation for the prediction of crop irrigation in future climate. Infrastructure and Ecology of Rural Areas, vol. 5, 2011, pp. 7-18. 
[16] Kuchar L., Iwański S. Rainfall evaluation for crop production until 2050-2060 and selected climate change scenarios for North Central Poland. Infrastructure and Ecology of Rural Areas, vol. 2, no. I, 2013, pp. 187-200.

[17] Kuchar L., Iwański S., Diakowska E., Gąsiorek E. 2015. Simulation of hydrothermal conditions for crop production purpose until 2050-2060 and selected climate change scenarios for North Central Poland. Infrastructure and Ecology of Rural Areas, vol. II, no. 1, pp. 319-334.

[18] Kuchar L., Iwański S., Diakowska E., Gąsiorek E. Assessment of meteorological drought in 2015 for North Central part of Poland using hydrothermal coefficient (HTC) in the context of climate change. Infrastructure and Ecology of Rural Areas, vol. I, no. 2, 2017, pp. 257-273.

[19] Rolbiecki S., Rolbiecki R., Rzekanowski Cz., Żarski J. The influence of sprinkler irrigation on yields of some vegetable crops in the region of Bydgoszcz, Poland. Acta Horticulturae, vol. 537, no. 2, 2000, pp. 871-877.

[20] Rolbiecki R., Rolbiecki S. Effects of micro-irrigation systems on lettuce and radish production. Acta Horticulturae, vol. 729, 2007, pp. 331-335. 